\title{
Determination of calcium and parathyroid hormone levels following hemithyroidectomy
}

\author{
Isabel Fernández Palop ${ }^{1 *} \mathbb{D}$, Cristina Fernández Martínez², María Jesús Segura Giménez², \\ M. Carmen Azorin Samper ${ }^{2}$ and Rafael García Fuster ${ }^{1}$
}

\begin{abstract}
Background and objective: Hypocalcemia is one of the main complications of thyroid surgery. We hypothesized that hemithyroidectomy may have an impact on serum parathyroid hormone (PTH) and calcium levels despite only one thyroid lobe is manipulated. The objective of this study was to analyze changes in serum PTH and calcium levels following hemithyroidectomy.

Methods: This is a prospective study of 53 patients who underwent thyroid lobectomy. The serum PTH level was determined in the preoperative period, $15 \mathrm{~min}$ after extraction of the surgical specimen, and $24 \mathrm{~h}$ and 3 weeks after surgery. Serum ionized calcium was also measured in the preoperative period and at $6 \mathrm{~h}, 24 \mathrm{~h}$ and 3 weeks after surgery. We assessed the postoperative calcium value and its relationship with the extent of fall in PTH levels in the postoperative period.

Results: None of the patients had the postoperative serum ionised calcium level less than $4 \mathrm{mg} / \mathrm{dl}$. The decrease in postoperative calcium was statistically significant at 6 and $24 \mathrm{~h}$ after surgery; there was no difference at 3 weeks post-surgery. The change in post-operative serum PTH levels followed a similar trend to postoperative serum calcium levels.

Conclusions: Although serum calcium level decreased after a lobectomy, it always remained above $4 \mathrm{mg} / \mathrm{dl}$. We conclude that hypocalcaemia is rare following hemithyroidectomy.
\end{abstract}

Keywords: Hypocalcemia, Hemithyroidectomy, Intraoperative PTH

\section{Background}

Thyroid lobectomy or hemithyroidectomy is a surgical procedure that consists of the removal of half of the thyroid gland, preserving the contralateral lobe. Indications for this procedure include: unilateral symptomatic goiter, toxic adenoma or thyroid nodules with suspicious or undetermined characteristics in fine needle aspiration cytology [1].

\footnotetext{
* Correspondence: isabelfpalop@gmail.com

'Universidad Católica de Valencia San Vicente Mártir, Valencia, Spain Full list of author information is available at the end of the article
}

The advantage of this technique is that it retains functional thyroid tissue, thus theoretically avoiding levothyroxine replacement therapy. In addition, it also reduces the risk of complications in the contralateral lobe.

One of the most frequent complications of thyroid surgery is post-surgical hypoparathyroidism and associated hypocalcemia.

Parathyroid hormone (PTH) is one of the three main hormones that modulate calcium and phosphate homeostasis. The other two are: calcitriol (1,25-dihydroxyvitamin D) and fibroblast growth factor 23 (FGF23) [2]. Control of serum ionized calcium concentration is

C C The Author(s). 2021 Open Access This article is licensed under a Creative Commons Attribution 4.0 International License, which permits use, sharing, adaptation, distribution and reproduction in any medium or format, as long as you give appropriate credit to the original author(s) and the source, provide a link to the Creative Commons licence, and indicate if changes were made. The images or other third party material in this article are included in the article's Creative Commons licence, unless indicated otherwise in a credit line to the material. If material is not included in the article's Creative Commons licence and your intended use is not permitted by statutory regulation or exceeds the permitted use, you will need to obtain permission directly from the copyright holder. To view a copy of this licence, visit http://creativecommons.org/licenses/by/4.0/ The Creative Commons Public Domain Dedication waiver (http://creativecommons.org/publicdomain/zero/1.0/) applies to the data made available in this article, unless otherwise stated in a credit line to the data. 
mediated exclusively by $\mathrm{PTH}$, maintaining its concentration within a narrow range by stimulating renal tubular and bone resorption $[3,4]$.

PTH also stimulates the conversion of calcidiol (25hydroxyvitamin D) into calcitriol in renal tubular cells, thus stimulating intestinal absorption of calcium and bone turnover. Calcitriol feeds back to inhibit PTH secretion and inhibits PTH biosynthesis and proliferation of parathyroid cells.

When there is surgical injury to the parathyroid glands, insufficient PTH secretion occurs and, consequently, hypocalcemia develops. Severe hypocalcemia may produce symptoms such as seizures, cardiac arrythmias, heart failure or laryngospasm.

Although post-thyroidectomy hypocalcaemia is well documented in the literature, its incidence rate varies widely from 0.3 to $60 \%$ in different series [5-7].

Hypocalcemia due to hypoparathyroidism occurs, in most cases, without documented removal of the parathyroid glands. This fact implies that these glands are highly sensitive to the injury caused by surgical manipulation (ischemia, venous congestion). In the case of hemithyroidectomy, we assume that there will be no change in the serum calcium level when only one thyroid lobe is surgically manipulated, but there are few studies describing this.

In some studies, a higher incidence of hypoparathyroidism was found after total thyroidectomies compared to lobectomies or subtotal thyroidectomies [8, 9].

This study is based on the hypothesis that the manipulation of one of the two thyroid lobes can have some repercussion in the release of PTH and as a consequence serum calcium level.

The objective of our study was to compare the concentrations of serum PTH and calcium before and after hemithyroidectomy and to evaluate if there is a decrease in their concentrations in the post-operative period.

We also aimed to evaluate possible correlations between serum PTH and calcium levels.

\section{Material and methods}

\section{Patients and procedures}

This is a prospective observational study of patients who underwent hemithyroidectomy at our center between February 2016 and March 2019. The study was approved by the Center's Ethics Committee. Patients with coexisting parathyroid or renal pathology were excluded.

A consecutive sampling was carried out, collecting data on the demographic characteristics of the patients and their thyroid pathology, the features of the surgery, the biochemical parameters and their evolution.

The following variables were recorded: sex, preoperative diagnosis, thyroid function, definitive pathological diagnosis, symptoms and signs of hypocalcemia, and other complications (recurrent laryngeal nerve paralysis, seroma, hematoma).

For the parathyroid glands, we recorded their number, condition and appearance at the end of surgery.

\section{Laboratory methods}

A blood sample was taken before the operation to determine the basal levels of serum ionized calcium, phosphorus and intact PTH.

We performed ionized calcium measurements because some studies have shown these to be more reliable than total calcium measurements for immediate and longterm follow-up of patients after thyroidectomy [10].

An intraoperative PTH measurement was performed immediately after thyroid lobectomy (15 min after the surgical specimen was removed). The percentage decrease in post-operative PTH compared to the preoperative value was calculated as:

\section{(PTHpostop-PTHpreop) x 100 PTHpreop}

A post-operative PTH level was determined $24 \mathrm{~h}$ and 3 weeks after surgery.

Ionized calcium and phosphorus measurements were obtained at $6 \mathrm{~h}, 24 \mathrm{~h}$ and 3 weeks after surgery.

Ionized calcium below $4.4 \mathrm{mg} / \mathrm{dl}$ was considered hypocalcemia. In patients with symptomatic hypocalcemia or with ionized calcium values equal to or less than $4 \mathrm{mg} /$ $\mathrm{dl}$, intravenous calcium, oral calcium, oral vitamin $\mathrm{D}$, or a combination was administered.

Ionized calcium concentration was analysed with direct potentiometry with a calcium ion-selective electrode combined with an external reference electrode, in Radiometer ABL-835 gasometer. The ionized calcium value was corrected to physiological $\mathrm{pH}$ of 7.4.

Intact PTH was determined with the Cobas E801 analyzer from Roche Diagnostics by electrochemical luminescence enzyme immunoassay (EQL) analysis.

The laboratory reference ranges for biochemical parameters used in the study were: serum PTH (15-75 pg/ $\mathrm{ml})$, ionized calcium $(4.40-5.20 \mathrm{mg} / \mathrm{dl})$ and serum phosphate $(2.5-4.5 \mathrm{mg} / \mathrm{dl})$.

\section{Statistical analysis}

Statistical analysis was performed using SPSS version 22 for Windows (Chicago, IL, USA).

We use the Student's t-test to compare the pre and post thyroidectomy variables, and a $P$-value $<0.05$ was taken as statistically significant.

\section{Results}

A total of fifty-three hemithyroidectomies were performed in our center between February 2016 and March 
Table 1 Patients characteristics

\begin{tabular}{ll}
\hline Characteristics & $\mathbf{n}(\%)$ \\
\hline Total patients & 53 \\
Male & $15(28.3)$ \\
Female & $38(71.7)$ \\
Surgical indication & \\
Bethesda category IV & $23(43.4)$ \\
Nodule size increase & $20(37.7)$ \\
Compressive symptoms & $6(11.3)$ \\
Hyperfunction & $2(3.8)$ \\
Recurrent cyst & $2(3.8)$ \\
Lobectomy & \\
Right & $25(47.2)$ \\
Left & $28(52.8)$ \\
Definitive anatomopathological diagnosis & \\
Hyperplasia & $25(47.2)$ \\
Follicular adenoma & $20(37.7)$ \\
Hashimoto's thyroiditis & $4(7.5)$ \\
Thyroid carcinoma & $4(7.5)$ \\
Average age patients & 52.8 years (SD=14.3) \\
\hline
\end{tabular}

2019. These were operated on by the same team of surgeons.

The centre is a secondary-level hospital, with 30 years of experience in thyroid surgery, where about 60 thyroidectomies are carried out every year.

\section{Patient characteristics}

Demographic and clinical features of patients included in the study are shown in Table 1 . There were more women $(71.7 \%)$ then men $(28.3 \%)$. The average age of the patients was 52.8 years $(\mathrm{SD}=14.3)$.
Similar percentages of the patients underwent a left and a right hemithyroidectomy.

The most common indications for surgery were: follicular proliferation (Bethesda category IV) (43.3\%), increase in nodule size (37.7\%) and compressive symptoms (11.3\%).

The definitive anatomopathological diagnosis included hyperplasia (47.2\%), follicular adenoma (37.7\%), Hashimoto's thyroiditis (7.5\%) and thyroid carcinoma (7.5\%).

The carcinomas found were all papillary and less than $5 \mathrm{~mm}$ in size. In all cases, the finding of malignancy was incidental.

Paralysis of the recurrent laryngeal nerve occurred in one of the patients after surgery. This paralysis was transient and corrected in less than 3 months.

\section{PTH and calcium levels}

Preoperative mean serum calcium level was $4.8 \mathrm{mg} / \mathrm{dl}$ $(\mathrm{SD}=0.15)$; at $6 \mathrm{~h}$ the mean was $4.52 \mathrm{mg} / \mathrm{dl}(\mathrm{SD}=0.2)$; at $24 \mathrm{~h}: 4.5 \mathrm{mg} / \mathrm{dl} \quad(\mathrm{SD}=0.2)$ and at 3 weeks: $4.8 \mathrm{mg} / \mathrm{dl}$ $(\mathrm{SD}=0.15)$.

The mean serum phosphate level was: $3.35 \mathrm{mg} / \mathrm{dl}$ preoperative $(\mathrm{SD}=0.45) ; 3.38 \mathrm{mg} / \mathrm{dl}$ at $6 \mathrm{~h}(\mathrm{SD}=0.6)$; $3.10 \mathrm{mg} / \mathrm{dl}$ at $24 \mathrm{~h}(\mathrm{SD}=0.45)$ and $3.4 \mathrm{mg} / \mathrm{dl}$ at 3 weeks $(\mathrm{SD}=0,5)$.

PTH decrease was statistically significant between preoperative measurement (mean: $53.84 \mathrm{pg} / \mathrm{ml}$ ), and at $15 \mathrm{~min}$ (mean: $45.33 \mathrm{pg} / \mathrm{ml}, p=0.04$ ) and the day after surgery (mean: $42 \mathrm{pg} / \mathrm{ml}, p=0.038$ ). There was no difference between preoperative $\mathrm{PTH}$ and 3 weeks later (mean: $50.33 \mathrm{pg} / \mathrm{ml}$ ).

The longitudinal calcium and PTH profiles are shown in Fig. 1.

We have not been able to find any correlation between intra-operative PTH levels and calcium levels $6 \mathrm{~h}$ after surgery.
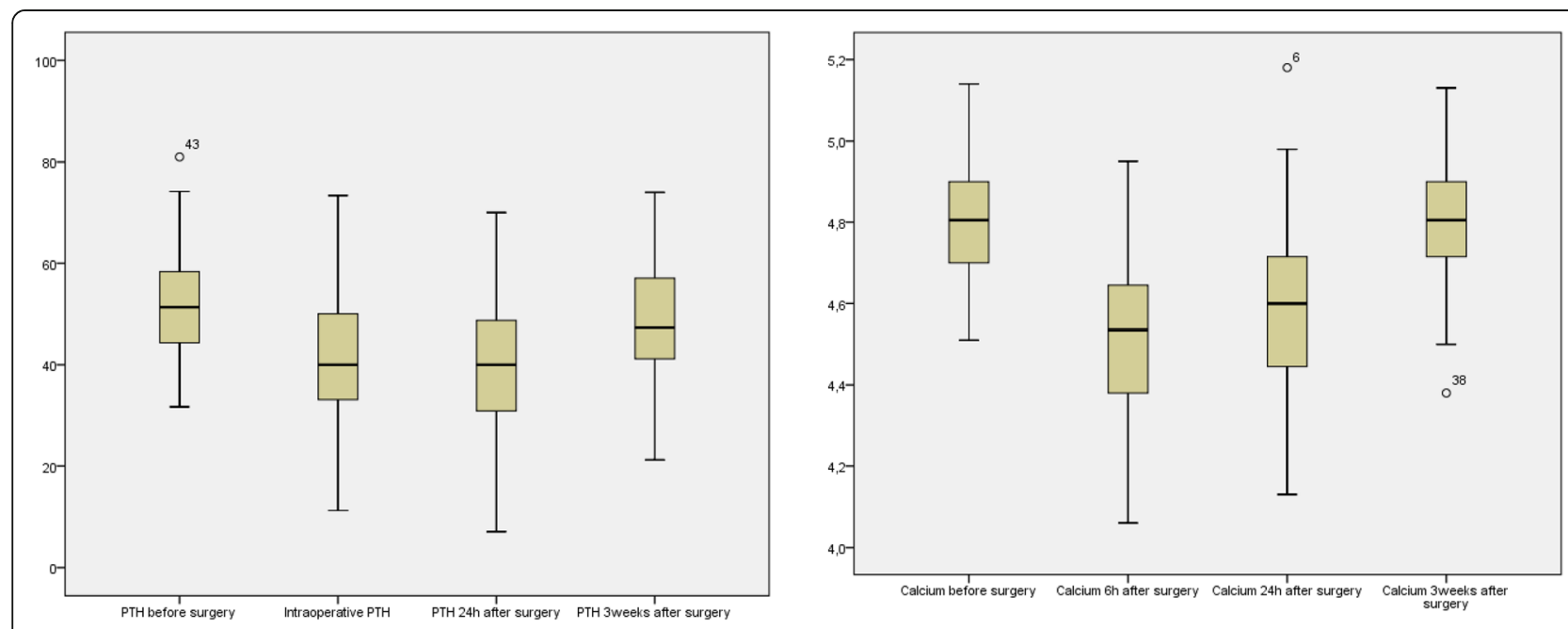

Fig. 1 Longitudinal profiles in calcium and PTH 


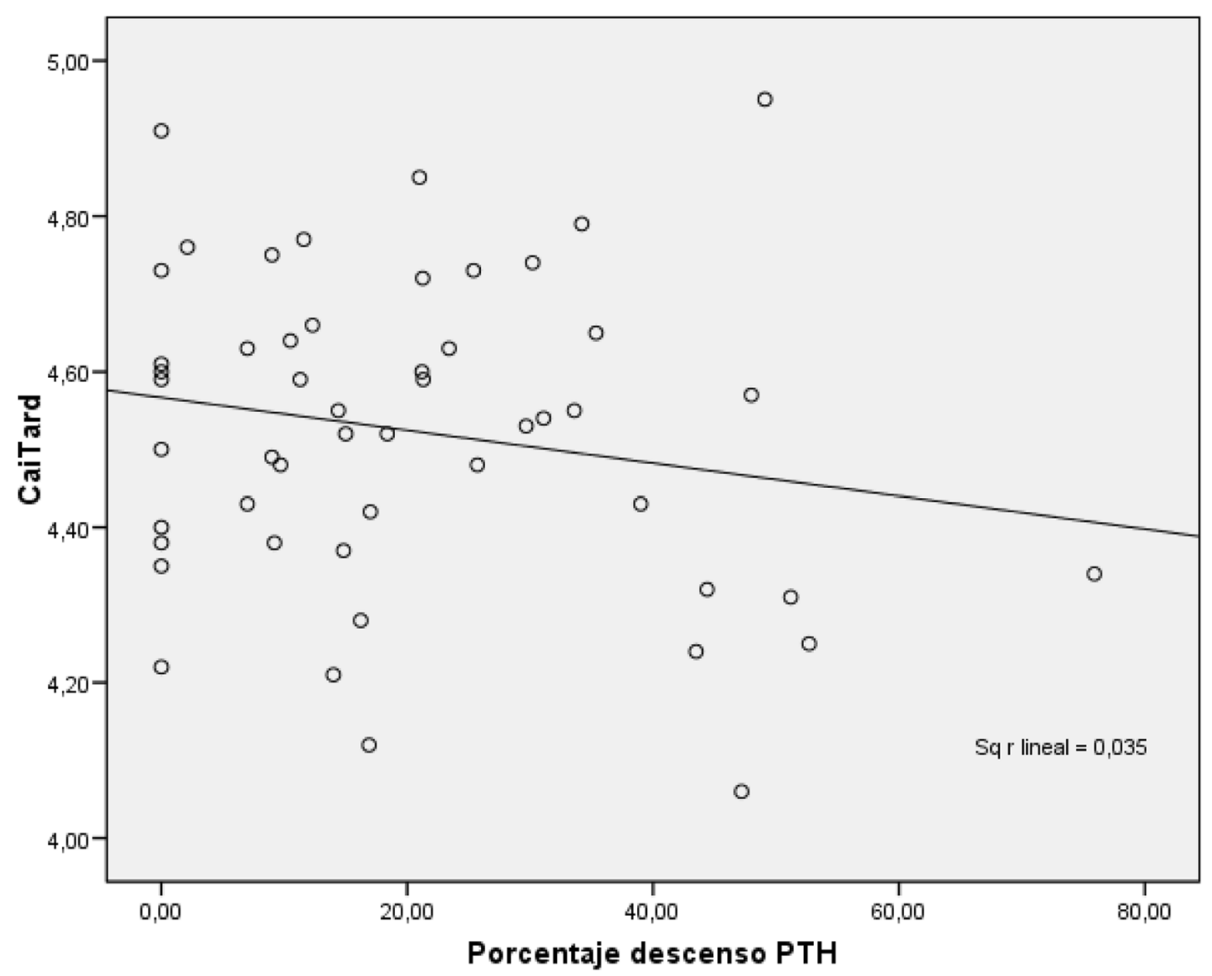

Fig. 2 Pearson's correlation for percentage decrease in PTH and calcemia obtained $6 \mathrm{~h}$ after the intervention

We compared the percentage decrease in PTH with the ionized calcium values at $6 \mathrm{~h}$ after surgery, and found an analogous trend. The trend line is descending, although R2 was not statistically significant (Fig. 2).

\section{PTH and calcium levels in relation to identification of parathyroid glands during surgery}

The total number of exposed parathyroid glands was 106.
Two parathyroid glands were identified during the procedure in 21 patients (39.6\%); a single gland in 28 patients $(45.3 \%)$ and no parathyroid gland was identified in 4 patients $(7.5 \%)$.

The characteristics of the parathyroid glands observed in the three groups are shown in Fig. 3.

In two of the cases, the presence of a parathyroid gland was described in the histology specimen.

We analysed calcium and PTH levels in each of these groups.

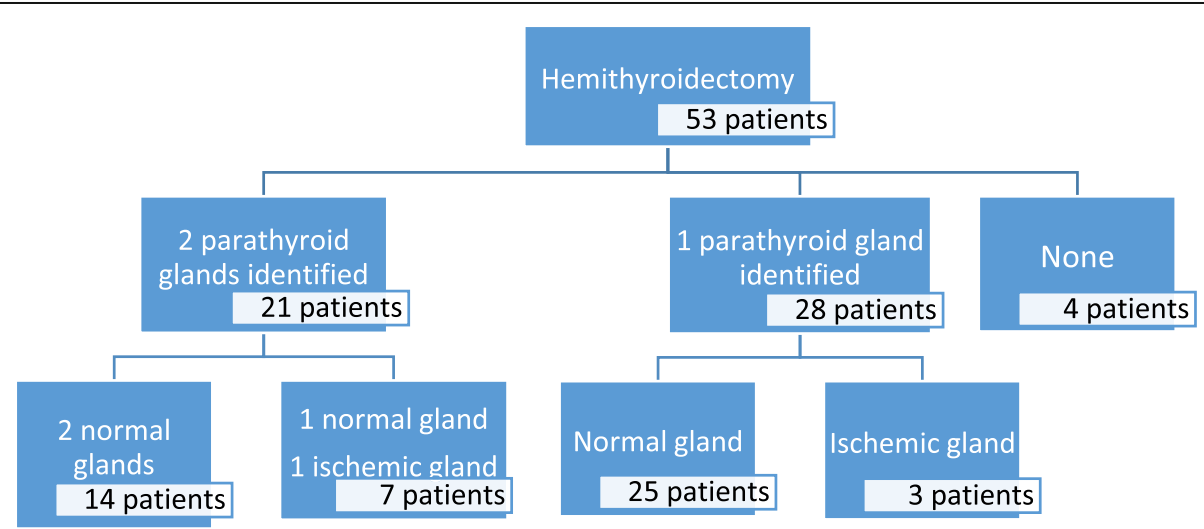

Fig. 3 Parathyroid glands identified in surgery and their characteristics 
In the group in which the two parathyroid glands identified as normal, the average serum calcium level 24 $\mathrm{h}$ after surgery is $4.56 \mathrm{mg} / \mathrm{dl}$ (SD 0.2) and the PTH $40.67 \mathrm{pg} / \mathrm{ml}$. In the group in which one of the parathyroids was described as ischemic or congestive, the mean serum calcium level $24 \mathrm{~h}$ after surgery was $4.46 \mathrm{mg} / \mathrm{dl}$ (SD 0.2) and the PTH $48 \mathrm{pg} / \mathrm{ml}$. In the group in which one parathyroid gland was found to in histology specimen the mean serum calcium level $24 \mathrm{~h}$ after surgery was $4.33 \mathrm{mg} / \mathrm{dl}$ (SD 0.3) and the PTH $47.7 \mathrm{pg} / \mathrm{ml}$.

We observed that the mean serum calcium level after hemithyroidectomy is higher in patients in whom both parathyroid glands have been identified as normal at surgery as compared to the other two groups, although the difference was not statistically significant. We observed similar PTH levels among the three groups.

\section{Discussion}

Hypocalcemia post-thyroidectomy as a multifactorial phenomenon is the most frequent clinical problem in patients undergoing thyroid surgery. The risk factors for post-thyroidectomy hypocalcaemia are: extension of the resection, group IV lymph node dissection, thyroidectomy as treatment of hyperthyroidism, central ligation of the lower thyroid artery, number of parathyroids identified and preserved during operation, and the surgeon's experience [11].

In our study, the differences between preoperative and 6- and 24-h serum calcium levels reached statistical significance.

This confirms our hypothesis that manipulation in a thyroid lobe has an impact on postoperative ionized calcium concentrations, although this decrease is small and recovers before 3 weeks.

We found no significant difference between preoperative and three-week calcium. We also found no difference in serum calcium levels at 6-h and 24-h after surgery, so one of the two measurements would be sufficient to monitor calcium levels in patient undergoing hemithyroidectomy.

We found that the early postoperative PTH decrease was statistically significant even though PTH levels remained within the reference range. This fact confirms the impact of surgery on the parathyroid glands. This repercussion can be documented immediately.

We found no difference between preoperative PTH and the level 3 weeks later, since the two contralateral glands remain intact following hemithyroidectomy.

The fact that we found no correlation between postoperative PTH levels and postoperative calcium levels may be related to the fact that there was no postoperative hypocalcemia in the sample. However, we have found that the decrease in postoperative PTH follows a trend analogous to calcium levels.
Hemithyroidectomy may be an ideal procedure to perform in a Major Outpatient Surgery (surgical procedures of medium complexity for which the patient is admitted to the hospital on the day of the operation and is allowed to return home the same day).

The most serious complications (bleeding and recurrent laryngeal nerve paralysis) appear in the first hours after surgery $[12,13]$. In the case of thyroid lobectomy, the possible recurrent laryngeal nerve paralysis would be unilateral, causing dysphonia, but not severe problems such as dyspnea or respiratory failure.

Our work allows us to guarantee the safety of the ambulatory surgery for hemithyroidectomy with respect to possible hypocalcemia. On the one hand, the decrease in serum calcium level does not reach below the normal reference range and, on the other hand, we can predict serum calcium level at $24 \mathrm{~h}$ post-surgery by measuring calcium level only at $6 \mathrm{~h}$ post-surgery.

\section{Conclusion}

This study indicates that, in patients undergoing hemithyroidectomy, there are no significant differences between preoperative and postoperative serum calcium levels. Hemithyroidectomy is a safe intervention, in which post-operative hypocalcaemia below $4 \mathrm{mg} / \mathrm{dl}$ is rare.

The absence of differences between serum calcium levels at six and $24 \mathrm{~h}$ after hemithyroidectomy in this study suggests that if the serum calcium is normal at $6 \mathrm{~h}$ postoperatively, hypocalcemia will be unlikely in the subsequent hours. This fact allows us to perform lobectomy in outpatient surgery.

\section{Abbreviations}

PTH: Parathyroid hormone

\section{Acknowledgements}

Not applicable.

Authors' contributions

All authors have contributed intellectually to the work, are eligible for authorship and have approved the final version of the work.

Funding

Not applicable.

Availability of data and materials

The datasets used and analysed in the current study are available from the corresponding author on reasonable request.

\section{Declarations}

Ethics approval and consent to participate

The authors declare that the study was reviewed and approved by the Ethics Committee of Sagunto Hospital. All patients included in the study signed a

written consent form giving us permission to use their data.

Consent for publication

The authors consent to the publication of the manuscript. 


\section{Competing interests}

The authors declare that they have no competing interests.

\section{Author details}

'Universidad Católica de Valencia San Vicente Mártir, Valencia, Spain.

${ }^{2}$ Hospital de Sagunto, Sagunt, Spain.

Received: 19 January 2021 Accepted: 19 May 2021

Published online: 03 June 2021

\section{References}

1. Haugen BR, Alexander EK, Bible KC, Doherty GM, Mandel SJ, Nikiforov YE, et al. 2015 American Thyroid Association management guidelines for adult patients with thyroid nodules and differentiated thyroid Cancer: the American Thyroid Association guidelines task force on thyroid nodules and differentiated thyroid Cancer. Thyroid. 2016;26(1):1-133 PubMed PMID: 26462967. Pubmed Central PMCID: 4739132.

2. Kumar R, Thompson JR. The regulation of parathyroid hormone secretion and synthesis. J Am Soc Nephrol. 2011;22(2):216-24 PubMed PMID: 21164021. Pubmed Central PMCID: 5546216.

3. Pak CY. Calcium metabolism. J Am Coll Nutr. 1989;8(Suppl):46S-53S PubMed PMID: 2681327.

4. Brown EM. Four-parameter model of the sigmoidal relationship between parathyroid hormone release and extracellular calcium concentration in normal and abnormal parathyroid tissue. J Clin Endocrinol Metab. 1983; 56(3):572-81 PubMed PMID: 6822654.

5. Testini M, Gurrado A, Lissidini G, Nacchiero M. Hypoparathyroidism after total thyroidectomy. Minerva Chir. 2007;62(5):409-15 PubMed PMID: 17947951.

6. Edafe O, Prasad P, Harrison BJ, Balasubramanian SP. Incidence and predictors of post-thyroidectomy hypocalcaemia in a tertiary endocrine surgical unit. Ann R Coll Surg Engl. 2014;96(3):219-23 PubMed PMID: 24780788. Pubmed Central PMCID: 4474053.

7. Pattou F, Combemale F, Fabre S, Carnaille B, Decoulx M, Wemeau JL, et al. Hypocalcemia following thyroid surgery: incidence and prediction of outcome. World J Surg. 1998;22(7):718-24 PubMed PMID: 9606288.

8. Pelizzo MR, Bernante P, Toniato A, Piotto A, Grigoletto R. Hypoparathyroidism after thyroidectomy. Analysis of a consecutive, recent series. Minerva Chir. 1998;53(4):239-44 PubMed PMID: 9701977. Ipoparatiroidismo dopo tiroidectomia. Verifica di una serie consecutiva e recente.

9. Wilson RB, Erskine C, Crowe PJ. Hypomagnesemia and hypocalcemia after thyroidectomy: prospective study. World J Surg. 2000;24(6):722-6 PubMed PMID: 10773126

10. Tartaglia F, Giuliani A, Sgueglia M, Patrizi G, Di Rocco G, Blasi S, et al. Is ionized calcium a reliable predictor of hypocalcemia after total thyroidectomy? A before and after study. II Giornale di chirurgia. 2014;35(12):27-35 PubMed PMID: 24690338. Pubmed Central PMCID: 4321580.

11. Thomusch O, Machens A, Sekulla C, Ukkat J, Brauckhoff M, Dralle H. The impact of surgical technique on postoperative hypoparathyroidism in bilateral thyroid surgery: a multivariate analysis of 5846 consecutive patients. Surgery. 2003;133(2):180-5 PubMed PMID: 12605179.

12. Harding J, Sebag F, Sierra M, Palazzo FF, Henry JF. Thyroid surgery: postoperative hematoma--prevention and treatment. Langenbeck's Arch Surg. 2006;391(3):169-73 PubMed PMID: 16555087.

13. Edis AJ. Prevention and management of complications associated with thyroid and parathyroid surgery. Surg Clin North Am. 1979;59(1):83-92 PubMed PMID: 582079

\section{Publisher's Note}

Springer Nature remains neutral with regard to jurisdictional claims in published maps and institutional affiliations.

Ready to submit your research? Choose BMC and benefit from:

- fast, convenient online submission

- thorough peer review by experienced researchers in your field

- rapid publication on acceptance

- support for research data, including large and complex data types

- gold Open Access which fosters wider collaboration and increased citations

- maximum visibility for your research: over $100 \mathrm{M}$ website views per year

At $\mathrm{BMC}$, research is always in progress.

Learn more biomedcentral.com/submissions 